\title{
ANALÝZA STOKOVEJ SIETE V MESTE TRNAVA
}

\author{
ANALYSIS OF SEWARAGE IN THE CITY OF TRNAVA
}

\author{
Marek Šutúš ${ }^{1}$, Gergély Rózsa, ${ }^{1}$ Štefan Stanko ${ }^{1}$
}

marek.sutus@stuba.sk

${ }^{1}$ Slovenská technická univerzita v Bratislave, Stavebná fakulta, Katedra zdravotného a environmentálneho inžinierstva, Radlinského 11 , 81005 Bratislava

\begin{abstract}
Abstrakt
Typickým objektom na jednotných stokových siet’ach sú odl'ahčovacie komory, ktoré slúžia na reguláciu prietoku dažd'ovej vody. Ich úlohou je znížit' množstvo dažd'ovej vody privádzaných na čistiareň odpadových vôd a tým ju ochránit' pred pret'ažením. Tieto vody sú zmesou splaškových vôd a vôd z povrchového odtoku, a preto obsahujú rôzne kontaminanty. V meste Trnava bola zaznamenaná znížená kvalita vôd v recipiente Trnávka. Je preto potrebné zistit’ aktuálny stav týchto komôr a zistit’ či splńajú súlad s aktuálnymi environmentálnymi predpismi.
\end{abstract}

\section{Klíčová slova}

Stoková siet', odl'ahčovacia komora, znečistenie

\begin{abstract}
A typical object on uniform sewer networks are relief chambers, which serve to regulate the flow of rainwater. Their task is to reduce the amount of rainwater supplied to the wastewater treatment plant and thus protect it from overload. These waters are a mixture of sewage and surface runoff water and therefore contain various contaminants. In the city of Trnava, reduced water quality was recorded in the Trnávka recipient. It is therefore necessary to determine the current state of these chambers and to determine whether they comply with current environmental regulations.
\end{abstract}

\section{Key words}

Sewerage, combined sewer overflow, pollution

\section{1 ÚVOD}

Poznáme dva typy kanalizačných systémov: delený a jednotný. V delenom máme separované potrubie pre splaškovú vodu a dažd'ovú v jednotnom prúdi všetko v jednom potrubí.

"Mestské drenážne systémy odvádzajú dva typy prietokov: odpadovú a dažd’ovú. Dôležitou etapou v histórii mestskej kanalizácie bolo napojenie odpadových vôd na priekopy a prírodné toky, ktorých pôvodnou funkciou bolo odvádzanie dažd'ovej vody." [1].

\section{STOKOVÝ SYSTÉM V MESTE TRNAVA}

V rámci existujúceho intravilánu, mesto Trnava vybudovalo mechanicko-biologickú čistiareň odpadových vôd, ktorá je napojená na verejnú kanalizáciu. Čistiareň sa nacháza v blízkosti obce Zeleneč, južne od Trnavy. Kanalizačný systém odvádza dažd’ové, priemysel'né a odpadové vody.

Charekter stokovej siete je jednotný. Stoková siet’ má približnú dížku 111,3 km ku roku 2015 a na túto siet' je pripojených aj d'al'ších 36 obcí v okolí Trnavy. V centre mesta a v starších budovách je stoková siet' pret’ažená a zastaralá, respektívne poddimenzovaná. Toto pret’aženie sprevádza aj zvíšené prevádzkové tažkosti a je čiastočnou príčinou pluviálnych povodní. Na zabezpečenie priameho odtoku daždových vôd do recipientu sa na stokovej sieti nachádza 22 odl’ahčovaích komôr. Na odvádzanie daždových vôd z priemyselnej zóny PSA a Technopol je vybudovaná samostatná daždová kanalizácia. Tieto vody sú tiež odvádzané do recipientu Trnávka [2]. 


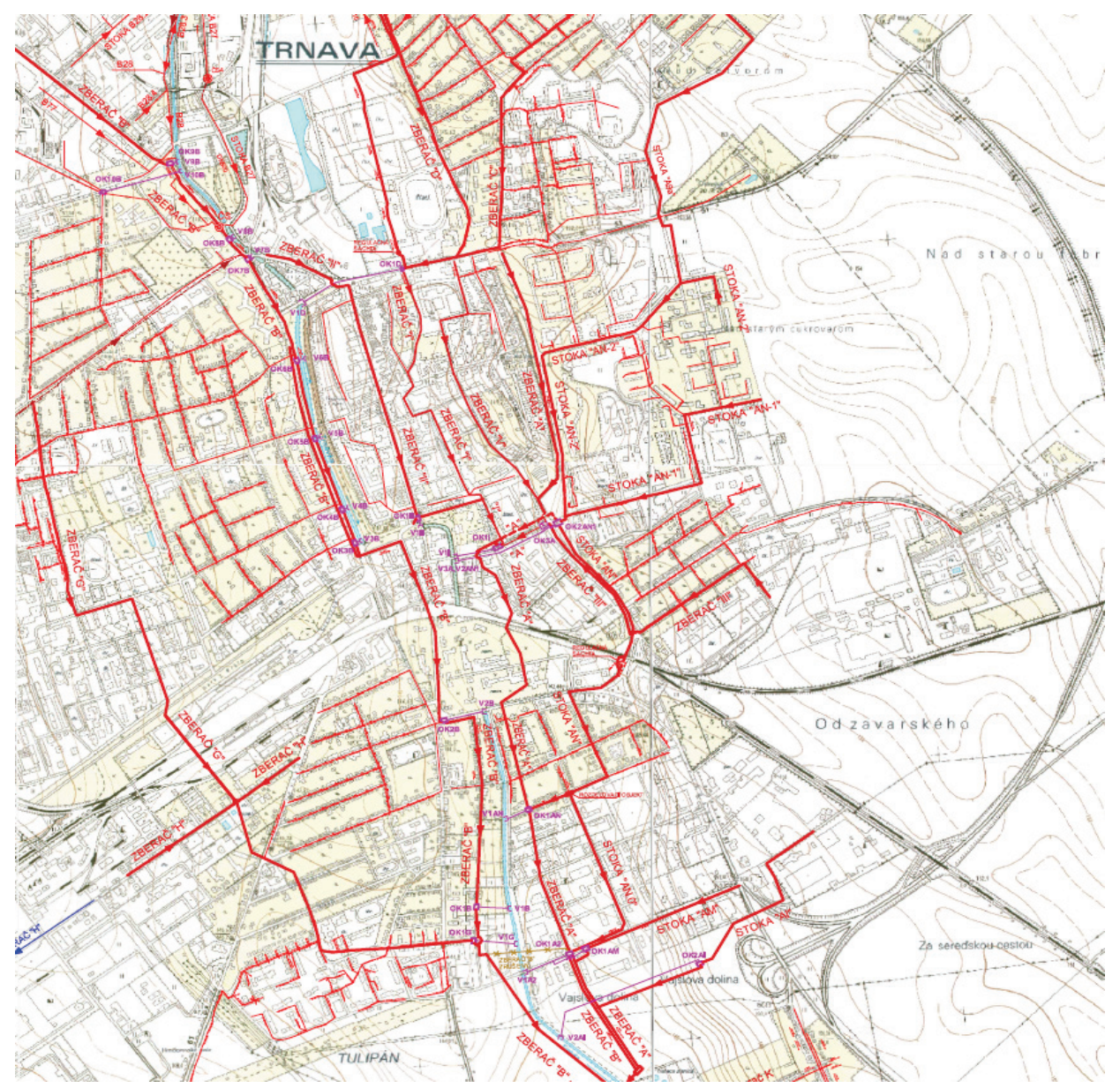

Obr. 1 Stoková siet' mesta Trnava.

\section{METODIKA}

Pokial' sa na stokovej sieti nachádza viac jako 10 odl'ahčovacích komôr, je potrebné stanovit' počet prípadov odl'ahčenia a vykonat' odborné posúdenie odtokových a zrážkových pomerov, pričom každá OK musí spínat' základné kritérium - zmiešavací pomer [3].

Podl'a $\S 6$ odstavca 3 Nariadenia vlády č. 269/2010, je zmiešavací pomer definovaný ako "pomer priemerného denného prietoku komunánlnych odpadových vôd v nedaždivom období k prietoku vody z povrchového odtoku, ktorý je vypúštaný do čistiarne odpavých vôd počas dažd’a." Minimálny pomer má hodnutu 1:4.

Pri čase odtoku cez kanalizačnú siet' ku OK 15 minút alebo viac, počet prípadov odl'ahčenia nesmie prekročit' 15 krát za rok. Pri čase kratšom ako 15, počet prípadov odl'ahčenie nesmie v dlhodobom priemere prekročit' 20krát za rok [3].

\section{Meranie prietoku}

Podmienky pre meranie neboli ideálne. Vo väčšine prípadoch merania bola sedimentácie na dne, upchatie ale aj kontaminácia OK. Merania boli vykonané medzi 8:00 až 11:00, v časoch predpokladaného priemerného alebo nadpriemerného prietoku. 
Tab. 1 Merané hodnoty híbky a prietoku.

\begin{tabular}{|c|c|c|c|c|c|c|c|c|c|c|c|}
\hline Označenie & $\begin{array}{c}\text { OK } \\
1\end{array}$ & $\begin{array}{c}\mathrm{OK} \\
2\end{array}$ & $\begin{array}{c}\text { OK } \\
3\end{array}$ & $\begin{array}{c}\mathrm{OK} \\
4\end{array}$ & $\begin{array}{c}\text { OK } \\
5\end{array}$ & $\begin{array}{c}\text { OK } \\
6\end{array}$ & $\begin{array}{c}\text { OK } \\
7\end{array}$ & $\begin{array}{c}\text { OK } \\
8\end{array}$ & $\begin{array}{c}\text { OK } \\
9\end{array}$ & $\begin{array}{c}\text { OK } \\
10\end{array}$ & $\begin{array}{c}\text { OK } \\
11\end{array}$ \\
\hline $\begin{array}{l}\text { Híbka } \\
\text { [mm] }\end{array}$ & 30 & 200 & 50 & 200 & 150 & 400 & 150 & 100 & 30 & 50 & 200 \\
\hline $\begin{array}{c}\text { Rýchlost' } \\
{\left[\mathrm{m} \cdot \mathrm{s}^{-1}\right]}\end{array}$ & 0,4 & 0,3 & 1,35 & 0,2 & 0,2 & 0,05 & 0,5 & 0,1 & 0,4 & 0,7 & 1 \\
\hline Označenie & $\begin{array}{c}\text { OK } \\
12\end{array}$ & $\begin{array}{c}\text { OK } \\
13\end{array}$ & $\begin{array}{c}\text { OK } \\
14\end{array}$ & $\begin{array}{c}\text { OK } \\
15\end{array}$ & $\begin{array}{c}\text { OK } \\
16\end{array}$ & $\begin{array}{c}\text { OK } \\
17\end{array}$ & $\begin{array}{c}\text { OK } \\
18\end{array}$ & $\begin{array}{c}\text { OK } \\
19\end{array}$ & $\begin{array}{c}\text { OK } \\
20\end{array}$ & $\begin{array}{c}\text { OK } \\
21\end{array}$ & $\begin{array}{l}\text { OK } \\
22\end{array}$ \\
\hline $\begin{array}{l}\text { Híbka } \\
\text { [mm] }\end{array}$ & 500 & 50 & 300 & 300 & 100 & 400 & 550 & 100 & 20 & 50 & \\
\hline $\begin{array}{c}\text { Rýchlost' } \\
{\left[\mathrm{m}^{\prime} \mathrm{s}^{-1}\right]}\end{array}$ & 0,3 & 0,5 & 0,4 & 0,3 & 0,5 & 0,35 & 0,2 & 0,2 & 0,1 & 0,2 & \\
\hline
\end{tabular}

Pre výpočet zmiešavacieho pomeru je potrebné určit' prítok do OK. Prítok bol stanovený na základe meranej híbky a rýchlosti.

$$
v_{z v}=\sqrt{\frac{2 g *\left(p+h_{p}+i_{0} * l-m * D\right)}{\alpha+\xi_{v t}+\lambda * \frac{l}{D}}}
$$

Rýchlost' prúdenia v škrtiacej stoke sa vypočíta podl'a rovnice $(1), \mathrm{kde}: g\left(\mathrm{~m} / \mathrm{s}^{2}\right)$ - gravitačné zrýchlenie, $p(\mathrm{~m})$ - výška tlaku vody nad odtokom škrtiacej klapky, $h_{\mathrm{p}}(\mathrm{m})$ - výška prepadu, $i_{0}(-)$ - sklon odtoku škrtiacej klapky, $l(\mathrm{~m})$ - dížka odtoku škrtiacej klapky, $m$ (-) - koeficient na určenie tlakového vedenia, $D(\mathrm{~m})$ - priemer odtoku škrtiacej klapky, $\alpha(-)$ - Coriolisovo číslo, $\xi$ vt (-) - koeficient miestnych strát na vstupe do škrtiacej klapky, $\lambda(-)$ - koeficient trenia.

$$
Q_{o d t}=v_{z v} \frac{\pi * D^{2}}{4}
$$

Prietok v šktriacej stoke sa následne vypočíta podl'a rovnice (2), kde: $v_{\mathrm{zv}}(\mathrm{m} / \mathrm{s})$ - rýchlost' v škrtiacej stoke, $\pi(-)$ - Ludolfovo číslo, $D(\mathrm{~m})$ - priemer potrubia.

Pri niektorých potrubiach musela byt' prietoková plocha odhadnutá, nakol'ko nie všetky potrubia mali kruhový priemer.

\section{Zmiešavací pomer}

Na posúdenie budeme uvažovat' zo stavom ked' začne voda prepadat' cez priepadovú hranu.

$$
n=\frac{Q_{o d t}}{Q_{24}}-1
$$

Zmiešavací pomer vypočítame podl'a rovnice (3), kde: Qodt $\left(\mathrm{m}^{3} \cdot \mathrm{s}^{-1}\right)$ - prietok do ČOV počas dažd'a, $\mathrm{Q}_{24}\left(\mathrm{~m}^{3} \cdot \mathrm{s}^{-1}\right)$ priemerný denný prietok v beždaždovom období.

\section{Počet odl'ahčení}

Na základe odhadovaného času dotoku 15 minút a orografických charakteristík pre stanicu Trnava - Vrútky bola stanovená výdatnost' blokového dažd’a.

$$
m_{0}=\left[(1-\tau) *\left(Q_{m} * \frac{n_{0}}{Q_{d}}\right)^{0,83} *\left(1+c_{1} * \frac{\log }{p}\right)+\tau\right]^{-3}
$$


Počet odl'ahčení bol vypočítaný podl’a rovnice (4), kde: $\tau(-)$ - klimatický koeficient, $c_{1}(-)$ - miestny koeficient, $Q_{\mathrm{m}}\left(1 . \mathrm{s}^{-1}\right)$ - priemerný prietok komunálnej odpadovej vody, $Q_{\mathrm{d}}\left(1 . \mathrm{s}^{-1}\right)$ - návrhový prietok dažd’ovej vody prúdiacej $\mathrm{z}$ povodia nad $\mathrm{OK}, n_{0}(-)$ - je zmiešavací pomer v konkrétnej $\mathrm{OK}, p$ (rok-1)-periodicita.

\section{VÝSLEDKY}

Tab. 2 Prehl'ad výsledkov.

\begin{tabular}{cccc}
\hline Označenie & $\begin{array}{c}\text { Zmiešavací } \\
\text { pomer }\end{array}$ & $\begin{array}{c}\text { Počet } \\
\text { odl'ahčení }\end{array}$ & Stav \\
\hline OK1 & {$[-]$} & {$[-]$} & \\
OK2 & 4,10 & 4,1 & Vyhovuje \\
OK3 & 14,3 & 35,6 & Nevyhovuje \\
OK4 & 10,3 & 2,1 & Vyhovuje \\
OK5 & 16,9 & 10,3 & Vyhovuje \\
OK6 & 14,8 & 3,6 & Vyhovuje \\
OK7 & 6,9 & 8,5 & Vyhovuje \\
OK8 & 20 & 18,3 & Nevyhovuje \\
OK9 & 8,3 & 2,4 & Vyhovuje \\
OK10 & 10,1 & 12,8 & Vyhovuje \\
OK11 & 1,2 & 14,1 & Vyhovuje \\
OK12 & 2,8 & 51 & Nevyhovuje \\
OK13 & 11,8 & 63,6 & Nevyhovuje \\
OK14 & 4,1 & 39,3 & Nevyhovuje \\
OK16 & 33,2 & 39,9 & Nevyhovuje \\
OK17 & 4,2 & 1,3 & Vyhovuje \\
OK18 & 6,6 & 20,5 & Nevyhovuje \\
OK19 & 31,4 & 5,4 & Vyhovuje \\
OK20 & 11,5 & 14,3 & Vyhovuje \\
OK21 & 18,6 & 35 & Nevyhovuje \\
OK22 & 6,1 & 20,8 & Nevyhovuje \\
\hline
\end{tabular}

Podl'a výsledkov v Tab. 2 možeme vydiet' že 9 odl'ahčovaních komôr z celkového početu 22 nevyhovuje z hl'adiska zmiešavacieho pomeru, počtu odl'ahčení alebo oboch kritérií na raz. V prípade nevyhovujúceho stavu je potrebná stavebná úprava $\mathrm{OK}$.

\section{ZÁVER}

Ciel’om tejto práce bola analýza súčastného stavu odl'ahčovacách komôr v meste Trnava. Pri obhliadke objektov a stokovej siete bol zistený zlý stavený stav. Výsledkom bolo vytypovanie tých odl'ahčovacích komôr, ktoré nespíňajú legislatívne limity na počet odl'ahčení a zmiešavací pomer. Na týchto komorách sa následne plánuje využitie CFD modelovania na zlepšenie stavu tak, aby boli splnené všetky podmienky dané legislatívou. Podl'a [3] §6 odstavca 2, odl'ahčovacie komory musia byt' vybavené zariadením na zachytávanie plávajúcich látok. Takéto zariadenie nebolo v žiadnej OK, preto je nutná stavebná úprava všetkých komôr.

\section{Pod'akovanie}

Táto práca bola podporovaná na základe podpory Vedeckej grantovej agentúry MŠVVaŠ SR a SAV s označením VEGA 1/0574/19 a APVV-0372-12 a na základe Grantu STU „Mladý výskumník STU“ pod 
akronymom FYMOVOSS, ktorý je financovaný z centrálnych zdrojov Slovenskej technickej univerzity $\mathrm{v}$ Bratislave.

\section{Použité zdroje}

[1] Butler D., Davies J. W.: Urban Drainage. ISBN 0-203-84905-1. Spon Press is an imprint of the Taylor \& Francis Group. 2 Park Square. Milton Park. Abingdon. Oxon 2011.

[2] Technická infraštruktúra. Trnava.sk [online]. Posledná zmena 26.05.2021. [Cit. 23.11.2021]. Dostupné z: https://www.trnava.sk/sk/clanok/technicka-infrastruktura.

[3] Nariadenie vlády č. 269/2010, Nariadenie vlády Slovenskej republiky ktorým sa ustanovujú požiadavky na dosiahnutie dobrého stavu vôd.

[4] Trnavská vodárenská spoločnost', a.s., 2015, Rekonštrukcia odl'ahčovacích komôr - Technické správy / výkresová dokumentácia. 